\title{
Etika informasi dalam menjaga kerahasian dokumen rekod medis pada Puskesmas Biak Muli Aceh Tenggara
}

\author{
Wahyudi Sekedang \\ Mahasiswa Pascasarjana Universitas Islam Negeri Sunan Kalijaga \\ Konsentrasi Ilmu Perpustakaan dan Informasi \\ Email: sekedangwahyudi@gmail.com
}

\begin{abstract}
This research entitled information ethics in maintaining the confidentiality of medical record documents at the Health Center of Biak Muli, Southeast Aceh. This study aims to find out how the ethics of information on medical records officers in maintaining the confidentiality of medical record documents at the Biak Muli Health Center in Southeast Aceh. This study uses a qualitative approach that produces descriptive data. The technical steps in collecting data are through literature study, interviews, and observation. The results showed that, information ethics applied by medical records officers in maintaining medical record documents at the Biak Muli Health Center in Southeast Aceh District had not been implemented well. Likewise, regarding patient privacy contained in medical record documents, confidentiality has not been properly maintained by medical records officers. While the act of leaking medical records is a legal action, where the patient suffers from material and material losses from the act.
\end{abstract}

Keywords: Information Ethics, Documents, Medical Records, Privacy

\begin{abstract}
ABSTRAK
Penelitian ini berjudul etika informasi dalam menjaga kerahasian dokumen rekod medis pada Puskesmas Biak Muli Aceh Tenggara. Penelitian ini bertujuan untuk mengetahui bagaimana etika informasi petugas rekam medis dalam menjaga kerahasian dokumen rekod medis pada Puskesmas Biak Muli Aceh Tenggara. Penelitian ini menggunakan metode pendekatan kualitatif yang menghasilkan data berupa deskriptif. Teknik langkah-langkah dalam pengumpulan data ialah melalui studi kepustakaan, wawancara, dan observasi. Hasil penelitian menunjukan bahwa, etika informasi yang diterapkan oleh petugas rekod medis dalam menjaga dokumen rekod medis pada Puskesmas Biak Muli Kabupaten Aceh Tenggara belum diterapkan dengan baik. Begitu juga mengenai privasi pasien yang terdapat dokumen rekod medis belum dijaga kerahasiannya dengan baik oleh petugas rekod medis. Sementara Tindakan pembocoran rahasia rekod medis merupakan tindakan yang hukum, dimana pasien mengalami kerugian berupa material dan imaterian dari tindakan tersebut.
\end{abstract}

Kata Kunci: Etika Informasi, Dokumen, Rekod Medis, Privasi. 


\section{A. PENDAHULUAN}

Arsip merupakan informasi utama yang dimiliki oleh suatu lembaga dan keberadaanya sangat penting untuk keberlangsungan lembaga tersebut. Undang-Undang Nomor 7 yang dikeluarkan pada tahun 1971 pasal 1, arsip ialah dokumen atau naskah yang diciptakan atau diperoleh oleh lembaga/badan pemerintah, pihak swasta, dan perorangan, baik dalam bentuk tersendiri maupun gabungan dalam rangka penyelenggaraan negara. Di dalam ilmu kearsipan, arsip terbagi menjadi dua, yaitu arsip statis dan arsip dinamis. Begitu juga tehadap lembaga pemerintah, dimana arsip yang terdapat pada lembaga pemerintah meliputi arsip dinamis dan arsip statis.(Mirmani 2011, 5) Namun di dunia kesehatan, terdapat penamaan arsip tersendiri atau biasa disebut dengan dokumen rekod medis. (Judi et al. 2017)

Menteri kesehatan telah mengeluarkan peraturan Menkes No. 269 tahun 2008, rekam medis atau rekod medis ialah kumpulan yang di dalamnya terdapat catatan ataun ulasan yang berhubungan dengan identitas pasien, pengobatan, tindak, hasil pemeriksaan, dan segala bentuk pelayanan atau tindakan medis lain yang telah diberikan kepada seorang pasien. Melalui rekod medis, maka pasien memiliki bukti yang sah dimata hukum yang bisa dipertanggung jawabkan. Dengan demikian setiap proses pemeriksaan atau pelayanan kesehatan, pihak rumah sakit maupun sejenisnya berkewajiban menyelenggarakan rekod medis. Selain itu rekod medis berguna sebagai catatan maupun rekaman terjadi transaksi atau suatu peristiwa yang terjadi pada kegiatan pelayanan kesehatan. Menurut Fadlun, pelayanan rekod medis yang baik ditandai dengan kecepatan pelayanan dan tersedianya rekod medis saat dibutuhkan.(Fadlun 2017, 12)

Melihat informasi yang terdapat pada dokumen rekod medis sangat penting dan harus dijaga kerahasiaan dan keamanannya. Pemerintah telah mengatur melalui PERMENKES No. 269 tahun 2008 dalam pada pasal 10 ayat 1 bahwa isi berkas rekod medis mengandung nilai kerahasiaan yang harus dijaga karena di dalam rekod medis mengandung riwayat pengobatan pasien dari awal sampai akhir pasien tersebut berobat. Selain itu undang-undang mengenai praktik kedokteran No. 29 tahun 2004 pada pasal 47 ayat 2 juga memberikan penjelasan mengenai pentingnya menyimpan dan menjaga kerahasia dari rekod medis. Menjaga kerahasian rekod medis diperlukan pengetahuan mengenai tata kelola penyelenggaraan rekod medis yang sesuai dengan kaidah keilmuan.. Selain itu, etika menjadi faktor penting menjaga kerahasian rekod medis.(Nuraini 2018)

Etik merupakan aturan yang mengandung perintah maupun larangan yang berhubungan dengan baik dan/atau buruknya tingkah laku manusia, dengan kata lain etika merupakan perintah atau larangan yang harus dipatuhi dan dihindari oleh manusia.(Keraf 2010 , 2) Seperti dikatahui, rekod medis dilindungi oleh undang-undang setiap pembukaan informasi yang berkaitan dengan rekod medis harus mengikuti peraturan yang berlaku. Rekod medis hanya dibuka untuk keperluan yang berkaitan dengan pasien, kepentingan atau permintaan aparat hukum, permintaan pasien sendiri, atau kepentingan ketentuan perundang-undangan lainnya. Sehingga keamanan dan kerahasiaannya harus dijaga karena berhubungan dengan privasi pasien dari penyalahgunaan oleh oknum-oknum yang tidak bertanggung jawab.

Terlebih terhadap rekod medis seorang tokoh masyarakat maupun pejabat negara, dimana rekod medis dapat membahayakan orang tersebut jika tersebar luas. Untuk itu penulis akan membahas mengenai etika informasi dalam menjaga kerahasiaan rekod medis pada Puskesmas Biak Muli Kabupaten Aceh Tenggara. Berdasarkan observasi awal peneliti, tempat penyimpanan rekod medis kurang aman dalam menjaga kerahasiaan dokumen rekod medis. Tempat penyimpanan dapat diakses oleh petugas lain selain perekod medis dan dapat dengan mudahnya mengakses informasi rekod medis. 
Berdasarkan latar belakang diatas penulis tertarik untuk melakukan penelitian dengan judul etika informasi dalam menjaga dokumen rekod medis pada Puskesmas Biak Muli Kabupaten Aceh Tenggara.

\section{B. TINJAUAN PUSTAKA}

Dari penelurusan terhadap penelitian-penelitian sebelumnya,peneliti tidak menemukan fokus penelitian mengenai etika informasi. Akan tetapi, dari hasil penelurusa peneliti menemukan dua penelitian yang membahsa rehasian dokumen rekam medis. Adapun penelitian tersebut sebagai berikut:

Pertama penelitian yang berjudul kerahasiaan rekam medis di rumah sakit aveciena medika martapura. Penelitian bertujuan untuk mengetahui kerahasian dan proses pelepasan informasi pada unit kerja rekod medis dirumah sakit tersebut. Dari hasil penelitian ditemukan bahwa unit kerja rekam medis belum memiliki kebijakan mengenai kerahasian rekod medis secara merata dan masih pada akses ruang filling. Sementara pelepasan informasi rekod medis harus dengan izin tertulis yang ditujukan kepada pimpinan.(Rahmadiliyani and Faizal 2018) Kedua penelitian yang berjudul penerapan kode etik profesi perekam medis dibagian filing di rumah sakit umum daerah kabupaten karanganyar. Penelitian ini bertujuan ialah untuk menganalisa penerapan kode etik profesi perekam medis dalam menjaga dan menyimpan rekod medis, serta untuk mengetahui bagaiaman pelepasan informasi rekod medis. Hasil dari penelitian tersebut didapati bahwa kode etik perekam medis dalam menjaga rekod rekam medis yaitu dengan menyimpan dokumen menggunakan sistem penyimpanan metode sentralisasi, dan petugas rekam medis dalam pelepasan informasi rekod medis pasien dilakukan tidak sesuai kode etik profesi perekam medis.(Saputri, Sugiarsi, and Wujoso 2014)

\section{KAJIAN TEORI}

\section{Etika Informasi}

Dalam bahasa Yanani etika disebut dengan kata athikos, ethos memiliki sebuah makna/arti adat, kebiasaan, dan praktik.(Bagus 1996, 217) Sedangkan menurut istilah etika ialah ilmu yang berkaitan dengan baik dan yang buruk (secara moral) atau studi tentang moralitas.(Bagus 1996, 672) Menurut Khadijah, etika adalah sebuah kebiasaan seseorang di dalam masyarakat yang meliputi kata-kata/ucapan atau perbuatan yang nyata dalam bentuk tradisi lisan, bukan merupakan sebuah pedoman tertulis.(Jafar 2015, 15) Sedangkan informasi dalam Kamus Besar Bahasa Indonesia ialah penerangan, pemberitahuan (kabar atau berita tentang sesuatu). Menurut G. B. Davis dalam Atti, informasi ialah hasil dari data yang telah diproses menjadi sesuatu yang bermakna dan bermanfaat saat pengambilan keputusan dimasa sekarang dan/atau mendatang.(Ati and Taufik 2014, 5) Menurut Kursini dalam Gunawan, informasi ialah data yang telah diproses sehingga berarti bagi pegguna dan bermanfaat untuk menentukan arah kebijakan saat ini, atau mendukung sumber informasi.(Gunawan and Hastuti 2018, 149)

Sementara menurut Sulistyo Basuki dalam artikel yang berjudul etika informasi, etika informasi adalah cabang etika yang terpusat pada hubungan antara penciptaan (creation), pengorganisasian (organization), pemencaran (dissemination) dan penggunaan informasi serta standar etis dan kode moral yang mengatur perilaku manusia di masyarakat.(Basuki 2019, 5) Lebih lanjut Sulistyo Basuki menjelaskan, etika informasi berkaitan dengan topik seperti privasi, hak kekayaan intelektual, representasi yang adil (fair representation), non kejahatan jabatan/non maleficence.(Basuki 2019, 5) Jadi, dapat ditarik pengertian bahwa etika informasi merupakan perilaku seseorang dalam mengelola 
informasi sesuai dengan standar etis dan kode moral yang mengatur perilaku manusia di masyarakat.

\section{Dokumen Rekod medis}

Menurut Permenkes tahun 2008 nomor 269, kumpulan yang di dalamnya terdapat catatan ataun ulasan yang berhubungan dengan identitas pasien, pengobatan, tindak, hasil pemeriksaan, dan segala bentuk pelayanan atau tindakan medis lain yang telah diberikan kepada seorang pasien. Sedangkan menurut Departemen Kesehatan (Depkes) yang dikutip oleh Mangentang, rekod medis merupakan informasi yang tertulis dan informasi lainya yang berhubungan dengan pasien meliputi identitas/jatidiri, laboratorium, pemeriksaan fisik, anamneses, diagnosis serta segala pelayanan kesehatan yang diberikan tenaga kesehatan kepada pasien, baik bagi pasien rawat inap, rawat jalan, serta bagi pasien gawat darurat.(Mangentang 2018, 161)

Sedangkan menurut Hanafiah dan Amir, rekod medis adalah sebuah berkas yang berisikan dokumen mengenai pasien seperti jati diri, hasil pemriksaan, hasil anamnesis, serta segala bentuk catatan pelayanan kesehatan terhadap pasien deri waktu ke waktu. Catatan yang diberikan tenaga kesehatan dapat berupa tulisan, gambar, dan seiring kemajuan teknologi informasi bergeser ke bentuk elektronik seperti komputer, rekaman suara, dan mikrofilm. Secara sederhana, rekod medis ialah ku pula informasi pasi yang terekam dala bentuk cetak maupun elektonik, dimana kumpulan informasi tersebut meliputi identitas, hasil pemeriksaan, hasil anamnesis, segala bentuk tindakan medis yang diberikan atau diterima oleh pasien selama menerima pelayana kesehatan dari tenaga medis, baik bagi pasien rawat inap, rawat jalan, serta bagi pasien gawat darurat.

\section{METODE PENELITIAN}

Pada penelitian ini peneliti mengunakan pendekatan kualitatif yaitu bertujuan untuk memahami perilaku, tindakan, motivasi, dan persepsi yang dialami oleh subjek penelitian.(Moleong 2007, 4) Menurut Bogdan dan Taylor yang dikutip oleh Djunaidi penelitian kualitatif menghasilkan data deskriptif dari hasil pengamatan perilaku atau tingkah laku baik berupa tulisan, dan perkataan. Pendekatan kualitatif merupakan penelitian yang tidak dapat diukur mengunakan statistik atau melalui cara kuatifikasi.(Ghony and Almanshur 2012, 5) Penelitian ini dilakasanakan di Pusat kesehatan masyarakat (Puskesmas) Biak Muli, Kecamatan Bambel, Kabupaten Aceh Tenggara. Adapun tahapan pengumpulan data dalam penelitian ini melalui metode studi kepustakaan, observasi, dan wawancara.

\section{E. HASIL DAN PEMBAHASAN}

\section{Etika Informasi Dalam Menjaga Kerahasiaan Dokumen Rekod medis}

Etika informasi mulai digunkan oleh penulis pada tahn 1980-an seperti Koenig pada tahun 1989 dan Hauptman (1989) yang kemudian mendirikan majalah Jounal of Informations Ethics pada tahun 1992. Bahasan yang ada pada majalah Hauptman tersebut meliputi kerahasiaan, keandalan (realibility), kualitas dan penggunaan informasi dan data.(Basuki 2019, 5) Menurut Sulistyo Basuki, etika informasi merupakan standard etis dan moral seseorang di masyarakat yang berhubungan dengan informasi seperti penciptaan (creation), pengorganisasian (organization), dan pemencaran (dissemination) dan penggunaan infromasi.(Basuki 2019, 5) Dari hasil wawancara dan observasi peneliti mengenai penciptaan (creation), pengorganisasian (organization), dan pemencaran (dissemination) dan penggunaan infromasi pada Puskesmas Biak Muli Kabupaten Aceh Tenggara diperoleh hasil sebagai berikut: 


\section{a. Penciptaan (creation)}

Dari hasil wawancara dan observasi peneliti mengenai proses penciptaan dokumen rekod medis pada Puskesmas dimulai saat pasien mengisi berkas untuk rekod medis pada meja pendaftaran. Bagi pasien yang telah memiliki kartu berobat (telah berobat sebelumnya), maka pasien tidak perlu mengisi formulir. Pasien hanya perlu memperlihatkan kartu berobat kepada petugas kemudian petugas mencari rekod medisnya. Sedangkan bagi pasien yang tidak memiliki kartu berobat (baru pertama kali berobat), maka petugas akan melakukan pencatatan mengenai identitas, data sosial, nomor rekod medis, dan keluhan pasien pada buku register. Setelah dilakukan pemeriksaan oleh dokter, berkas rekod medis pasien disimpan menurut nomor rekod medisnya.

Penciptaan dokumen rekod medis pada Puskesmas Biak Muli Kabupaten Aceh Tenggara telah sesuai dengan teori. Menurut Departemen Kesehatan RI, alaur penciptaan dokumen rekod medis dimulai saat pasien mendaftar di loket untuk mendapatkan kartu berobat, kemudian pasien membawa kartu berobat ke tempat ketempat penerimaan pasien, setelah itu petugas penerimaan pasien mencatat pada buku register, hingga dokumen rekod medis disimpan setelah dilakukan pemeriksaan oleh dokter.

b. Pengorganisasian (organization)

Pengorganisasian merupakan rangkaian pengolahan pada kegiatan teknis yang memungkinkan dokumen arsip diorganisasikan, tertata secara sistematis dan disimpan sehingga dapat ditemukan kembali secara efisien dan efektif.(Hartono 2016, 14) Pengolahan rekod medis atau (assembling) pada Puskesmas Biak Muli Kabupaten Aceh Tenggara ialah meliputi merakit, menata, menyusun, dan merapihkan formulir-formulir rekod medis. Kegiatan tersebut menggunakan metode penyimpanan rekod medis berdasarkan nomor pasien, yaitu nomor rekod medis pada saat pasien masuk rumah sakit (admission patient number).

Pengorganisasian dokukem rekod medis pada Puskesmas Biak Muli telah mengikuti standar pengorganisasia. Kegiatan pengolahan yang yang meliputi pemberian nomor dokumen rekod medis, assembling, dan penyimpanan telah sesuai dengan teori. Pemberian nomor dilakukan dengan metode penomoran secara unit (unit nimbering system). Pasien akan mendapatkan nomor pada saat pertama kali melakukan pemeriksaan kesehatan, dan nomor itu akan tetap digunkan oleh pasien ketika berkunjung dikemudian hari (tanpa nomor baru). Pada kegiatan assembling seperti kegiatan merakit, menata, menyusun, dan merapihkan formulirformulir rekod medis dilakukan sesuai dengan penomorannya. Sedangkan kegiatan penyimpanan rekod medis pasien menggunakan metode penyimpanan sentralisasi.

c. Pemencaran (dissemination)

Pemencaran informasi (dissemination) adalah suatu kegiatan dalam menyampaikan informasi terhadap target sasaran penerima informasi baik melalui media konvensional, media interpersonal, maupun media baru (internet). Pada Puskesmas Biak Muli Kabupaten Aceh Tenggara, pemecaran informasi atau penyebaran informasi dokumen rekod medis tidak menggunakan alat bantu teknologi informasi. Dokumen rekod medis pada dikelola secara konvensional oleh petugas pada Puskesmas Biak Muli Kabupaten Aceh Tenggara.

d. Penggunaan Informasi

Dokumen rekod medis hanya dipergunakan bagi kebutuhan organisasi yaitu untuk keperluan dokter untuk melihat riwayat kesehatan pasien ketika melakukan pemeriksaan. Sedngkan selain untuk keperluan dokter, informasi dokumen rekod 
medis dapat dipinjamkan dengan ketentuan petugas mencatat siapa yang meminjam dan keperluannya. Peminjaman dokumen rekod medis, maka petugas akan mencatat siapa yang meminjam dan keperluanya pada sebuah buku ekspedisi.

Penggunaan informasi pada dokumen rekam harus mengikuti peraturan yang telah ditentukan, pemberian informasi dapat dilakukan kepada pihak ketika dengan menunjukan surat kuasa yang telah ditandatangani oleh pasien, dimana pada surat kuasa harus disebutkan bahwasanya pihak ketiga dapat mengakses infomasi tentang dirinya pada rekod medis. Rekod medis yang telah didokumentasikan merupakan rahasia pasien yang harus didimpan dengan baik dan dijaga kerahasiaannya. Tidak boleh dibaca dan diketahuai oleh orang lain tanpa seizin pemilikinya yaitu pasien.

\section{Etika Dalam Menjaga Privasi Dokumen Rekod medis}

Di era globalisasi seperti saat ini, etika informasi berkaitan dengan topik seperti privasi, hak kekayaan intelektual, representasi yang adil (fair representation), non kejahatan jabatan/non maleficence.(Basuki 2019, 5) Namun dalam menjaga kerahasiaan rekod medis, topik etika informasi lebih dititik beratkan kepada privasi. Privasi ialah hak seseorang untuk mengendalikan atau menentukan informasi tentang dirinya yang boleh atau tidak boleh diketahui orang lain atau yang boleh atau tidak boleh disiarkan tanpa seizin yang bersangkutan.(Basuki 2019, 8) Privasi menuntut adanya perlindungan terhadap informasi tentang diri seseorang, mengharuskan akuratnya informasi dan tidak adanya penggunaan atau pembukaan informasi yang tidak diizinkan.(Anggara, W.E, and Djafar 2015, 3) Rekod medis yang telah didokumentasikan merupakan rahasia pasien yang harus didimpan dengan baik dan dijaga kerahasiaannya. Tidak boleh dibaca dan diketahuai oleh orang lain tanpa seizin pemilikinya yaitu pasien. Dari hasil observasi pada Puskesmas Biak Muli Kabupaten Aceh Tenggara peneliti mendapati tempat penyimpanan dokumen rekod medis tidak terkunci dan dapat diakses oleh tenaga kesehatan yang berada di puskesmas tersebut. Selain itu peminjaman dokumen rekod medis menggunakan sistem pencatatan pada buku, setiap peminjam menuliskan nama dan keperluan dalam peminjaman. Berdasarkan hasi wawancara peneliti terhadap dua informan yang mengelola dokumen rekod medis pada Puskesmas Biak Muli Kabupaten Aceh Tenggara, adapaun hasilnya sebagai berikut:

Peneliti menanyakan bagaimana anda menjaga kerahasian dokumen rekod medis? responden 01 menjawaban: "Kami melakukan pencatatan terhadap setiap dokumen yang keluar dari tempat rak penyimpanan, siapa yang menyimpan dan apa keperluan dari peminjaman dokumen rekod medis tersbut." Lalu peneliti bertanya mengenai, Apakah ada larangan masuk bagi petugas selain perekod medis kedalam ruang penyimpanan rekod medis? Beliau menjawab: "Ada, namun terkadang masih ada juga petugas lain yang masuk tanpa menghiraukan himbauan.” Pertanyaaan selanjutnya, Adakah Alat pemdam kebakaran di tempat penyimpanan Dokumen rekod medis? Dalam hal ini responden 02 menjawab: "ada, itu telah ditempel didinding." Lanjut responde 01 menambahkan: Karena bahan dokumen rekod medis mudah terbakar, jadi harus disediakan alat pemadam kebakaran." Selanjutnya peneliti bertanya mengenai, Jika jam kerja sudah selesai, apakah ruang penyimpanan terkunci ? apabila dikunci, kuncinya siapa yang bawa atau diletakkan dimana ? Jika dipegang petugas? Dan petugas datang terlambat, apakah tidak menghambat pelayanan? Responden 01 menjawab: Setelah selesai jam kerja, kunci kami letakkan diatas ventilasi ruang penyimpanan. Jadi siapa yang datang duluan, dia yang membuka pintu. Responden 02 menambahkan: dulu salah satu dari kami membawanya pulang ke rumah, namun terjadi keterlambatan diluar rencana menyebabkan terhambatnya pelayanan rekod 
medis. Jadi kami memutuskan untuk meletakkan di ventilasi udara pintu tempat penyimpanan setelah selesai jam kerja.

Pivasi dokumen rekod medis pada puskesmas Biak Muli Kabupaten Aceh Tenggara belum dijaga kerhasiannya dengan maksimal. Terlihat pada tempat penyimpanan dokumen rekod medis yang tidak terkunci sehingga dapat diakses oleh semua tenaga kesehatan pada Puskesmas. Padahal menurut teori tempat penyimpnanan rekod medis haru dikunci bila tidak digunakan, agar keharian dokumen rekod medis tejaga dengan baik. Selain tenaga kesehatan dapat keluar-masuk ke dalam tempat penyimpanan tanpa ada larangan baik verbal maupun non verbal. Sesuai dengan teori, selain perekod medis atau tenaga kesehatan yang telah diberi wewenang dalam mengelola dokumen rekod medis dilarang masuk, hal ini untuk menghindari pencurian dokumen rekod medis. Selain itu, akses masuk yang tidak dibatasi berdampak terhadap penyalahgunaan akses informasi dokumen rekod medis. Sebab tidak dibatasinya akses masuk keruang penyimpanan menjadikan setiap orang dapat dengan mudah membuka dokumen rekod medis. Pembukaan informasi yang tidak memiliki izin merupakan melanggar undang-undang, dikarenakan dalam mengakses informasi dokumen rekod medis harus mendapatkan izin dari pemiliknya.

\section{Sanksi Terhadap Pembocoran Informasi Dokumen Rekod medis}

Dokumen rekod medis merupakan bagian dari privasi rekod yang dilindungi oleh undang-undang dalam hal akses terhadapnya.(Basuki 2019, 10) Dalam hal ini menjaga kerahasiaan rekod medis telah diatur melalui UU No. 29 tahun 2004 mengenai peraktik kedokteran dan melalui Permenkes Nomor: 269/MENKES/PER/III/2008 mengenai kerahasiaan rekod medis. Adanya undang-undang tersebut bertujuan untuk melindungi dan menjaga kerahasiaan privasi pasien dari penyalahgunaan pembukaan informasi. Pembukaan akses informasi yang tidak memiliki izin merupakan salah bentuk melanggar hukum dan melanggar kode etik profesi informasi.(Sudjana 2017) Kode etik profesi merupakan standar moral yang yang ditetapkan oleh asosiasi profesi dalam menjalankan tugas dan tanggung jawab dalam profesinya.(Mangesti 2017, 13)

Perekod medis memiliki etika profesi yang dikeluarkan oleh Profesional Perekod medis dan Informasi Kesehatan (PORMIKI) yaitu sebuah organisasi dari perekod medis. Sama halnya dengan oragnisasi pengelola informasi seperti profesi pustakawan, dokter, arsiparis dan lain sebagainya memiliki kode etik profesi yang dikeluarkan oleh organisasi profesinya. Tindakan pembocoran rahasia rekod medis merupakan tindakan yang bersifat melanggar hukum.(Sudjana 2017, 275) dimana pasien mengalami kerugian berupa material dan imaterial dari tindakan tersebut.(Susilowati, Surjoseputro, and Silviawati 2018, 18) Pembocoran rahasia kedokteran maupun rekaman medis dapat dikenai sanksi berupa pidana, perdata, dan administratif:(Susilowati, Surjoseputro, and Silviawati 2018, 18)

a. Kitab Undang-Undang Hukum Perdata (Pasal 1365, 1366 dan 1367)

b. Kitab Undang-Undang Hukum Pidana (Pasal 112 dan 322)

c. Administratif (PP No. 10 Tahun 1966) pelaku pembocoran tetap dikenakan sanksi meskipun pasien telah memaafkan dan tidak menempuh jalur hukum.

\section{F. PENUTUP}

\section{Kesimpulan}

Etika informasi yang diterapkan oleh petugas rekod medis dalam menjaga dokumen rekod medis pada Puskesmas Biak Muli Kabupaten Aceh Tenggara belum diterapkan dengan baik. Dari empat aspek penilaian tiga diataranya telah diterapkan dengan baik yaitu dalam penciptaan, pengorganisasian, dan diseminasi. Sementara pada aspek penggunaan informasi tidak sesuai dengan kaidah penggunaan dokumen rekod medis yang harus dijaga 
kerahasiaannya. Hal tersebut dapat dilihat dari tempat penyimpanan dokukem rekod medis yang dapat diakses oleh selain rekam medi, peminjaman dokukemn rekod medis yang tidak memiliki izin, dan tempat penyimpnan yag tidak terkunci. Selanjutnya, etika petugas rekod medis dalam menjaga privasi yang termuat dalam dokumen rekod medis tidak dijalankan dengan baik. Pembukaan dokumen rekod medis dapat dilakukan oleh setiap orang, dikarenakan akses masuk terhadap tempat penyimpanan yang tidak dibatasi. Tindakan pembocoran rahasia rekod medis merupakan tindakan yang bersifat melanggar hukum. dimana pasien mengalami kerugian berupa material dan imaterial dari tindakan tersebut. Pembocoran rahasia kedokteran maupun rekaman medis dapat dikenai sanksi berupa pidana, perdata, serta administratif.

\section{Saran}

Berdasarkan permasalahan diatas, peneliti ingin memberikan beberapa saran untuk dijadikan masukkan bagi Puskesmas Biak Muli Kabupaten Aceh Tenggara mengenai etika informasi dalam menjaga kerahasiaan dokumen rekod medis, saran-saran tersebut sebagai berikut:

1. Sebaiknya pihak Puskesmas mengadakan pelatihan tentang etika informasi dalama menjaga privasi dokumen rekod medis.

2. Ruang penyipanan dokumen rekod medis hendaknya dalam keadaan terkunci, agar orang lain yang selain petugas tidak bisa masuk.

3. Petugas rekod medis hendanya melalukan teguran terhadap orang yang masuk kedalam tempat penyimpanan dokumen rekod medis, baik secara verbal maupun non verbal.

4. Peminjaman atau akses terhadap dokumen rekod medis hendaknya memiliki izin dari pemilik yaitu pasien atau melalaui surat pemberian kuasa.

\section{DAFTAR PUSTAKA}

Anggara, Supriyadi W.E, and Wahyudi Djafar. 2015. Menyeimbangkan Hak: Tantangan Perlindungan Privasi Dan Menjamin Akses Keterbukaan Informasi Dan Data Di Indonesia. Jakarta: ICJR.

Ati, Sri, and Amin Taufik. 2014. "Dasar-Dasar Informasi."

Bagus, Lorens. 1996. Kamus Filsafat. Jakarta: PT Gramedia Pustaka Utama.

Basuki, Sulistyo. 2019. "Etika Informasi." Media Pustakawan 26 (1): 1-8. https://doi.org/10.37014/medpus.v26i1.171.

Fadlun, Fadlun. 2017. "Sistem Pelayanan Administrasi Rekam Medik Rawat Inap Di Rumah Sakit Umum Daerah (RSUD) Poso.” Katalogis 5 (3). http://jurnal.untad.ac.id/jurnal/index.php/Katalogis/article/view/8677.

Ghony, M. Djunaidi, and Fauzan Almanshur. 2012. Metode Penelitian Kualitatif. Yogyakarta: Ar-Ruzz Media.

Gunawan, Fahmi, and Heksa Biopsi Puji Hastuti. 2018. Senarai Penelitian Pendidikan, Hukum, Dan Ekonomi Di Sulawesi Tenggara. Yogyakarta: Deepublish.

Hartono. 2016. Dasar-Dasar Organisasi Informasi. Jakarta: Sagung Seto.

Jafar, St Khadijah. 2015. "Penerapan Kode Etik Pustakawan Di Perpustakaan Universitas Islam Negeri Alauddin Makassar.” PhD Thesis, Universitas Islam Negeri Alauddin Makassar.

Judi, Judi, Kusuma Estu Werdani, Salma Binti Purwaningsih, and Purwanti. 2017. "Tata Kelola Dokumen Rekam Medis Sebagai Upaya Menjaga Rahasia Medis di 
Pelayanan Kesehatan.” Jurnal Manajemen Informasi Kesehatan Indonesia (JMIKI) 5 (1): 96-104-104. https://doi.org/10.33560/.v5i1.156.

Keraf, A. Sonny. 2010. Etika Lingkungan Hidup. Jakarta: Penerbit Buku Kompas.

Mangentang, Fera Retno. 2018. "Kelengkapan Resume Medis Dan Kesesuaian Penulisan Diagnosis Berdasarkan ICD-10 Sebelum Dan Sesudah JKN Di RSU Bahteramas." Jurnal Administrasi Rumah Sakit Indonesia 1 (3). https://doi.org/10.7454/arsi.v1i3.2181.

Mangesti, Yovita Arie. 2017. "Konstruksi Kode Etik Profesi dalam Bingkai Nilai Keindonesiaan." Vocatio: Jurnal Ilmiah Ilmu Administrasi dan Sekretari 1 (1): 1122.

Mirmani. 2011. Materi Pokok Pengantar Kearsipan. Jakarta: Universitas Terbuka.

Moleong, Lexy J. 2007. Metode Penelitian Kualitatif. Bandung: Remaja Rosdakarya. Nuraini, Novita. 2018. "Analisis Sistem Penyelenggaraan Rekam Medis Di Instalasi Rekam Medis RS 'X' Tangerang Periode April-Mei 2015.” Jurnal Administrasi Rumah Sakit Indonesia 1 (3). https://doi.org/10.7454/arsi.v1i3.2180.

Rahmadiliyani, Nina, and Faizal Faizal. 2018. "KERAHASIAAN REKAM MEDIS DI RUMAH SAKIT AVECIENA MEDIKA MARTAPURA." Jurnal Manajemen Informasi Kesehatan Indonesia (JMIKI) 6 (2): 69-78-78. https://doi.org/10.33560/.v6i2.189.

Saputri, Anggita, Sri Sugiarsi, and Hari Wujoso. 2014. "PENERAPAN ETIKA PROFESI PETUGAS REKAM MEDIS DI RUMAH SAKIT UMUM DAERAH KOTA SURAKARTA TAHUN 2013." Rekam Medis 8 (2). https://ejurnal.stikesmhk.ac.id/index.php/rm/article/view/307.

Sudjana, Sudjana. 2017. "Aspek Hukum Rekam Medis atau Rekam Medis Elektronik sebagai Alat Bukti Dalam Transaksi Teurapetik.” Veritas et Justitia 3 (2): 359-83. https://doi.org/10.25123/vej.2685.

Susilowati, Indah, Wisnaningsih Surjoseputro, and Dika Silviawati. 2018. "Perlindungan Hukum Terhadap Hak Privasi Dan Data Medis Pasien Di Rumah Sakit X Surabaya." Jurnal Wiyata: Penelitian Sains Dan Kesehatan 5 (1): 10-23. 